\title{
KSZTAŁTOWANIE SIĘ PREZYDENTURY W II RZECZPOSPOLITEJ POLSKIEJ NA TLE KONCEPCJI WZMOCNIONEJ PREZYDENTURY W REPUBLICE WEIMARSKIEJ ORAZ FINLANDII POD RZĄDAMI KONSTYTUCJI Z 1919 ROKU
}

Streszczenie. Po uzyskaniu niepodległości 11 listopada 1918 roku Polska stanęła przed wieloma wyzwaniami. Państwo było tworem utworzonym z połączonych terytoriów byłego zaboru pruskiego, austriackiego i rosyjskiego, które przez 123 lata były podporządkowane odmiennym systemom prawnym państw zaborczych. Niepodległa Polska w szybkim czasie musiała wypracować fundamenty pod własny, nowy ustrój. Nie ułatwiała tego walka o granice państwa polskiego, problemy gospodarcze, brak spójnego ośrodka władzy oraz wiele innych czynników destabilizujących sytuację w państwie. Duży wpływ na to jak kształtowały się relacje między głównymi organami władzy na gruncie prawa konstytucyjnego, ale także w praktyce odegrał Józef Piłsudski, któremu udało się połączyć lokalne rządy w jedną władzę i tym samym stworzyć zalążki II Rzeczpospolitej. Analiza polskich rozwiązań konstytucyjnych kształtujących prezydenturę w tamtym okresie, wzbogacona zostanie o rozważania na temat wprowadzenia koncepcji silnej prezydentury w Republice Weimarskiej, a także Finlandii pod rządami konstytucji z 1919 roku. Wprowadzone rozwiązania kształtujące prezydenturę na tle polskiego konstytucjonalizmu, a także niemieckiego i finlandzkiego zostaną przeanalizowane pod kątem racjonalizacji systemu w kierunku wzmocnionej głowy państwa. Analiza powyższych rozwiązań pozwoli stwierdzić, iż polski ustawodawca na gruncie noweli sierpniowej z 1926 roku, a także konstytucji kwietniowej z 1935 roku wprowadził rozwiązania typowe dla koncepcji silnej prezydentury.

Słowa kluczowe: wzmocniona władza wykonawcza, prezydentura, II Rzeczpospolita, Republika Weimarska, Finlandia. 


\section{Wstęp}

$\mathrm{P}$ o uzyskaniu niepodległości 11 listopada 1918 roku Polska stanęła przed wieloma wyzwaniami. Państwo było tworem utworzonym z połączonych terytoriów byłego zaboru pruskiego, austriackiego i rosyjskiego, które przez 123 lata były podporządkowane odmiennym systemom prawnym państw zaborczych. Niepodległa Polska w szybkim czasie musiała wypracować fundamenty pod własny, nowy ustrój. Z pewnością nie ułatwiała tego walka o granice państwa polskiego, problemy gospodarcze, brak jednego spójnego ośrodka władzy ${ }^{1}$ oraz wiele innych czynników destabilizujących sytuację w państwie. Duży wpływ na to jak kształtowały się relacje między głównymi organami władzy na gruncie prawa konstytucyjnego, ale także w praktyce odegrał Józef Piłsudski, któremu udało się połączyć lokalne rządy w jedną władzę i tym samym stworzyć zalążki II Rzeczypospolitej.

Analiza polskich rozwiązań konstytucyjnych kształtujących prezydenturę począwszy od Małej Konstytucji z 20 lutego 1919 roku, Konstytucji Marcowej z 17 marca 1921 roku, noweli sierpniowej z 2 sierpnia 1926, a skończywszy na Konstytucji Kwietniowej z 23 kwietnia 1935 roku, pozwala ukazać relacje pomiędzy organami władzami, a także zjawisko wzmacniania władzy wykonawczej, niekoniecznie wynikające tylko z aktów prawnych, ale także z praktyki politycznej. Powyższe rozważania zostaną wzbogacone o analizę rozwiązań opartych na koncepcji silnej prezydentury w Republice Weimarskiej, a także Finlandii pod rządami konstytucji z 1919 roku. Wybór powyższych dwóch państw nie jest przypadkowy, gdyż Republika Weimarska zdaje się stanowić najbardziej reprezentatywny przykład wprowadzania koncepcji silnej prezydentury w omawianym okresie. Natomiast rozwiązania finlandzkie mające ten sam cel i stanowiące odzwierciedlenie tego samego procesu są zdaniem autorki często pomijane. Ponadto wszystkie trzy państwa łączy szczególna sytuacja wewnętrzna i zewnętrzna, w jakiej przyszło im wprowadzać omawiane rozwiązania.

${ }^{1}$ Równocześnie istniało kilka, niezwiązanych ze sobą ośrodków władzy. Powołana przez Cesarzy Niemiec i Austro-Węgier w 1917 roku Rada Regencyjna miała sprawować władzę na byłych rosyjskich terenach Królestwa Polskiego, aż do czasu powołania monarchy. Na terenie Galicji działa Rada Narodowa Księstwa Cieszyńskiego, która podporządkowała się powołanej w październiku 1918, w Krakowie, Polskiej Komisji Likwidacyjnej. W Wielkopolsce powstał powołany w Poznaniu, w lipcu 1918 Centralny Komitet Obywatelski, który w listopadzie zmienił nazwę na Naczelną Radę Ludową. Dodatkowo z nocy z 6 na 7 listopada 1918 r. w Lublinie został powołany Tymczasowy Rząd Ludowy Republiki Polskiej. Zob. Cz. Brzoza, L. Sowa, Historia Polski 1918-1945, Kraków 2006, s. 19-23. 


\section{Mała Konstytucja z 1919 roku}

Pierwszymi źródłami prawa państwowego o charakterze norm konstytucyjnych, w niepodległej Polsce był Dekret z 22 listopada 1918 roku o najwyższej władzy reprezentacyjnej Republiki Polskiej oraz Mała Konstytucja z 20 lutego 1919 roku. W powyższym dekrecie potwierdzono, że Polska będzie republiką, a Józef Piłsudski obejmie „jako Tymczasowy Naczelnik Państwa, Najwyższą Władzę Republiki Polskiej”2, aż do zwołania Sejmu Ustawodawczego. Do jego kompetencji należało mianowanie rządu, premiera i ministrów, którzy byli przed nim odpowiedzialni. Każdy projekt ustawodawczy uchwalony przez rząd wymagał jego zatwierdzenia. Zgodnie z dekretem, 20 lutego 1919 roku Piłsudski przekazał swoją władze nowo zwołanemu Sejmowi Ustawodawczemu. Tego też dnia Sejm wydał uchwałę o „powierzeniu Józefowi Piłsudskiemu dalszego sprawowania urzędu Naczelnika Państwa, aż do czasu uchwalenia konstytucji. Wprowadzała ona rządy parlamentarne w zaostrzonej postaci, odrzucając zasadę trójpodziału władzy"3. Jak wskazuje Michał Pietrzak Mała Konstytucja „stanęła na stanowisku koncentracji władzy państwowej w Sejmie Ustawodawczym" ${ }^{4}$. Sejm został

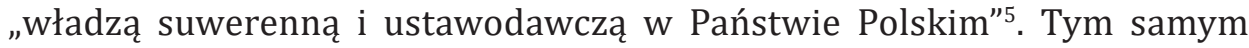
stał się źródłem władzy w państwie, którego forma inaczej niż w dekrecie z 22 listopada 1918 roku, w Małej Konstytucji nie została określona. W akcie nie została także wyznaczona dokładna kadencja organu ustawodawczego, którego głównym zadaniem było uchwalenie konstytucji. Całość uprawnień legislacyjnych spoczywała na nim. Tradycyjna kompetencja głowy państwa, jaką jest ogłaszanie ustaw została przeniesiona na Marszałka Sejmu. Władzę wykonawczą w państwie miał sprawować odpowiedzialny przed Sejmem Naczelnik Państwa i rząd. W porównaniu z kompetencjami Tymczasowego Naczelnika Państwa, kompetencje Naczelnika uległy znacznemu ograniczeniu. Do jego zadań należało reprezentowanie państwa na zewnątrz, powoływanie rządu, ale w porozumieniu z Sejmem. Był on najwyższym wykonawcą uchwał sejmowych w sprawach cywilnych i wojskowych. Wynika z tego, że „Naczelnik Państwa był po prostu agentem Sejmu w zakresie funkcji wykonawczej"6. Spowodowane było to skupieniem pełni władzy w Sejmie. Akty

2 T. Mołdawa, Konstytucje Polskie 1918-1998, Warszawa 1999, s. 20.

3 R. Balicki, Małe konstytucje w polskim prawie konstytucyjnym, [w:] Studia nad prawem konstytucyjnym, red. J. Trzciński, B. Banaszak, Wrocław 2005, s. 311.

${ }_{4}^{4}$ M. Pietrzak, Druga Rzeczpospolita, [w:] Historia ustroju i prawa polskiego, red. J. Bardach, B. Leśnodorski, M. Pietrzak, Warszawa 1999, s. 479.

5 T. Mołdawa, dz. cyt., s. 21.

${ }^{6}$ R. Kraczkowski, Mała konstytucja z dnia 20 lutego 1919 r., [w:] Małe konstytucje. Ustawy zasadnicze okresów przejściowych 1919-1947-1992, red. R. Jastrzębski, M. Zubik, Warszawa 2014, s. 16. 
Naczelnik były kontrasygnowane przez właściwego ministra. Przepisy konstytucji wprowadzały odpowiedzialność Naczelnika i rządu przed sejmem ${ }^{7}$.

Mimo, iż z przepisów Małej Konstytucji wynikała uprzywilejowana pozycja Sejmu Ustawodawczego, to praktyka konstytucyjna pokazała, że w rzeczywistości pozycja Józefa Piłsudskiego nadal była znacząca. Wynikało to nie tylko $\mathrm{z}$ jego silnych cech charakteru, ale także z tego, że zagwarantowano mu pełną swobodę, samodzielność we wszystkich sprawach związanych z organizowaniem armii i prowadzeniem działań wojennych, co w praktyce oznaczało posiadanie poważnego wpływu na politykę państwa wewnętrzną i zagraniczną państwa. Piłsudski pełnił w tym czasie stanowisko Naczelnego Wodza, a przez dłuższy okres obowiązywania Małej Konstytucji Polska znajdowała się w stanie wojny. Dowodem na to jest odezwa Wileńska jaką Piłsudski wydał po zajęciu Wilna ${ }^{8}$. W tym przypadku praktyka ustrojowa pokazała, że nie zawsze jest ona odzwierciedleniem formalnych założeń konstytucji, co jest wynikiem wielu uwarunkowań politycznych. Naczelnik Państwa zachował swoje kompetencje, aż do czasu wyboru prezydenta, którego urząd wprowadzono w konstytucji marcowej z 1921 roku.

\section{Konstytucja marcowa z 1921 roku}

Konsytuacja marcowa z 1921 roku była efektem pracy Sejmu Ustawodawczego. Powołana do tego Komisja Konstytucyjna przygotowała swój własny projekt ustawy zasadniczej odradzającego się państwa polskiego. Za nim jednak do tego doszło, zaistniało wiele projektów przyszłej konstytucji, pochodzących z inicjatywy rządu, partii politycznych, a nawet osób prywatnych ${ }^{9}$.

7 Wacław Komarnicki, autor pierwszej analizy Małej Konstytucji dopatrywał się podobieństwa tego zapisu o odpowiedzialności dwóch komponentów władzy wykonawczej przed sejmem w ustawodawstwie III Republiki Francuskiej, gdzie również parlament miał bardzo silną pozycję względem innych organów władzy państwowej. R. Kraczkowski, dz. cyt., s. 19.

${ }^{8}$ W kwietniu 1919 roku, Piłsudski, po zajęciu Wilna wydał odezwę do mieszkańców miasta o ich prawie do samostanowienia. Pod pismem widniał jego podpis, ale nie zostało sprecyzowano czy występuję jak Naczelnik Państwa czy też Naczelny Wódz. Akt nie był kontrasygnowany. W ten sposób powstała praktyka, ze dekrety Naczelnego Wodza nie były kontrasygnowane, mimo iż wykraczały poza typowo wojskowe decyzje. Zob. szerzej: S. Krukowski, Mała konstytucja z 1919, [w:] Konstytucje Polski, red. M. Kallas, Warszawa 1990, s. 14-17.

${ }^{9}$ Początkowo proponowano utworzenie monarchii konstytucyjnej z silną władzą króla, który miałby sprawować z parlamentem. Poza tą propozycją można wyróżnić trzy podstawowe projekty konstytucji marcowej. Pierwszy z nich to projekt Józefa Buzka, zwany też amerykańskim. Według niego Polska miała stać się prezydencką republiką federacyjną, w której skład weszłoby siedemdziesiąt ziem. Każda z nich miała posiadać własną konstytucję wraz z domniemywaniem na ich rzecz kompetencyjności. Drugi projekt zwany też francuskim, którego autorstwo obecnie przypisuje się Władysławowi Wróblewskiemu, wzorował się na rozwiązaniach ustrojowych III Republiki Francuskiej. Zakładał on republikańską formę rządów. 
Sejm Ustawodawczy uchwalił konstytucję nowo odrodzonego państwa 17 marca 1921 roku. Ustalała ona silną władzę ustawodawczą i słabą władzę wykonawczą. W miejsce działającego wcześniej Naczelnika Państwa wprowadzono pierwszy raz w historii urząd prezydenta. W pierwszym rozdziale wprowadzała ona zasadę republikańskiej formy rządów i trójpodział władzy. Według art. 2

władza zwierzchnia w Rzeczpospolitej należy do Narodu. Organami Narodu w zakresie ustawodawstwa są Sejm i Senat, w zakresie władzy wykonawczej - Prezydent Rzeczpospolitej łącznie z odpowiednimi ministrami, w zakresie sprawiedliwości wymiar sprawiedliwości - niezawisłe Sądy ${ }^{10}$.

O tym, iż pozycja Sejmu byłą wyraźnie dominująca w całym systemie, świadczy chociażby sama systematyka konstytucji. Rozdział drugi konstytucji został w całości poświęcony władzy ustawodawczej. Kadencja Sejmu i Senatu wynosiła 5 lat. Połączone izby parlamentu tworzyły Zgromadzenie Narodowe. Sejm posiadał kompetencje ustawodawcze, inicjatywę ustawodawczą, którą także miał rząd. Natomiast nie posiadał jej Senat. Sejm mógł się rozwiązać na mocy własnej uchwały przyjętej większością 2/3 głosów, przy obecności połowy ustawowej liczby posłów, a także przez Prezydenta przy zgodzie 3/5 ustawowej liczby Senatu. Do zadań Sejmu należały także kompetencje z zakresu kontroli, ustrojodawstwa ${ }^{11}$. Władzy wykonawczej został poświęcony dopiero rozdział trzeci Konstytucji. Jej piastunami byli Prezydent RP oraz rząd. Tym samym oba te podmioty były połączone w obrębie egzekutywy, a nie stanowiły dwóch całkowicie odrębnych elementów władzy wykonawczej. Sposób wyboru głowy prezydenta był jednym z głównych kwestii spornych w trakcie uchwalania konstytucji. Prawicy bardzo zależało na tym by prezydenta wybierał Sejm i Senat ${ }^{12}$, natomiast centrolewica

Ostatni z trzech głównych projektów, to propozycja Mieczysława Niedziałkowskiego. Zaproponował on utworzenie republiki z najwyższą władzą jednoizbowego sejmu, którego ustawy byłyby zatwierdzane w referendum. Projekt zakładał ograniczone kompetencje prezydenta, wybieranego przez Zgromadzenie Narodowe. Ważną role w procesie ustawodawczym miała odgrywać ludowa inicjatywa ustawodawcza. Ostatecznie Komisja Konstytucyjna tworząc swój własny projekt oparła się na propozycji Władysława Wróblewskiego. A. Ajnenkiel, Konstytucje Polski w rozwoju dziejowym 1791-1997, Warszawa 2001, s. 165-171.

10 T. Mołdawa, dz. cyt., s. 26.

11 Zob.: M. Pietrzak, dz. cyt., s. 482-483.

12 Prawica popierała ten sposób wyboru prezydenta, ponieważ tym samym dążyła do ograniczenia pozycji głowy państwa i jednocześnie chciała zwiększyć szanse zwycięstwa dla swojego kandydata. Endecja i pokrewne jej stronnictwa nie miały konkretnego kandydata, a Roman Dmowski był raczej ideologiem, inaczej niż Piłsudski, który odnajdywał się w roli praktyka. Dodatkowym argumentem, na który powoływała się prawica, była III Republika 
skłaniała się ku opcji polegającej na wyborze głowy państwa w wyborach powszechnych. Ostatecznie w tym sporze zwyciężyła opcja forsowana przez prawicę. Art. 39 wskazuje, że „Prezydenta Rzeczpospolitej wybierają na siedem lat bezwzględną większością głosów Sejm i Senat, połączone w Zgromadzenie Narodowe"13. Zwoływał je ustępujący Prezydent. Szczegóły wyboru prezydenta doprecyzowane zostały w ustawie z 27 lipca 1922 roku $^{14}$. Urząd prezydenta mógł zostać opróżniony z powodu śmierci, zrzeczenia się lub z innej przyczyny. Wtedy Zgromadzenie Narodowe zbierało się, by wybrać nowego prezydenta, a w razie potrzeby prezydenta zastępował Marszałek Sejmu. Według przepisów konstytucji głowa państwa nie odpowiadała parlamentarnie, ani cywilnie. Jedynie za zdradę kraju, pogwałcenie konstytucji, przestępstwo karne prezydent mógł być pociągnięty do odpowiedzialności przez Sejm uchwałą $3 / 5$ głosów przy obecności co najmniej połowy ustawowej liczby posłów, na co wskazuję art. 51 konstytucji marcowej. W zakresie wykonywania władzy wykonawczej do prezydent należało mianowanie i odwoływanie Prezesa Rady Ministrów, a na jego wniosek ministrów. Przy powoływaniu gabinetu musiał się on liczyć z żądaniami Sejmu. Oprócz tego pełnił typowe funkcje reprezentacyjne. Prezydent miał możliwość wypowiedzenia wojny i pokoju, ale tylko za uprzednią zgodą Sejmu. Jednocześnie był najwyższym zwierzchnikiem sił zbrojnych, a w czasie wojny mianował na wniosek rządu Naczelnego Wodza, którym sam być nie mógł. Do jego kompetencji względem parlamentu należało podpisywanie ustaw wraz z ministrami oraz zarządzanie ich publikacji. Wszystkie akty prawne prezydenta musiały być kontrasygnowane przez premiera i odpowiedniego ministra, na których to spoczywała odpowiedzialność za ich treść, co jest zawarte w art. 44. W konstytucji jasno jest powiedziane, że „Prezydent Rzeczpospolitej sprawuje władzę wykonawczą przez odpowiedzialnych przed Sejmem ministrów i podległych im urzędników"15. O słabości pozycji prezydenta w systemie ukształtowanym przez Konstytucje marcową świadczy też to,

Francuska, gdzie prezydent był wybierany właśnie w ten sposób. W dużej mierze, chodziło także o to, iż bała się ona kandydatury Piłsudskiego, dlatego cały czas dążyła do osłabienia pozycji prezydenta; S. Krukowski, dz. cyt., s. 84.

13 T. Mołdawa, dz. cyt., s. 36.

${ }^{14}$ Według jej przepisów, jeżeli w pierwszym głosowaniu żaden z kandydatów nie uzyska bezwzględnej większości ważnych głosów, zarządza się powtórne głosowanie, w ten sam sposób. Jeżeli drugie głosowanie również nie da pomyślnego wyniku, trzecie głosowanie odbywa się tak samo, lecz z tą różnicą, że kandydat, który otrzymał najmniej głosów odpada. Jeśli trzecie głosowanie nie da rezultatu, to zarządza się kolejne. Jeżeli w dwóch następujących po sobie głosowaniach głosy rozdzielą się równo pomiędzy więcej niż dwóch kandydatów, to los rozstrzyga, którego z nich się wykluczy. Gdy pozostanie tylko dwóch kandydatów i w ciągu dwóch kolejnych głosowań uzyskają równą ilość głosów, to wtedy o wygranym rozstrzyga los.

15 T. Mołdawa, dz. cyt., s. 37. 
że nie posiadał on ustawodawczego veta, inicjatywy ustawodawczej. Kolejnym przejawem jego słabej roli są ograniczenia prawa rozwiązania Sejmu i Senatu, o których była mowa powyżej. Prezydent nie miał prawa wydawania dekretów, a tylko rozporządzeń wykonawczych. W konstytucji marcowej możemy zauważyć liczne podobieństwa do konstytucji III Republiki Francuskiej, a wraz z nimi wiele podobnych wad ${ }^{16}$.

Na przykładzie konstytucji marcowej możemy mówić o racjonalizacji systemu, ale rozumianej jako instytucjonalizacja, ukonstytuowanie się pewnym zasad, reguł funkcjonowania systemu rządów ${ }^{17}$. W tym przypadku ową instytucjonalizacją było przyjęcie przepisów w konstytucji, które wprowadziły w Polsce system parlamentarny z osłabioną pozycją prezydenta. Konstytucja marcowa niemalże od momentu uchwalenia budziła wiele kontrowersji i głosów krytyki, które akcentowały jej wadliwe rozwiązania. Wytykano jej nadmierne ograniczenie władzy prezydenta, często też mocniejsze uprzywilejowanie Sejmu względem Senatu. Po 12 maja 1926 roku, gdy Józef Piłsudski dokonał zamachu stanu, temat reformy systemu rządów stał się oczywisty. Rząd Kazimierza Bartla wystąpił z projektem zmiany Konstytucji Marcowej, który po licznych transformacjach został uchwalony 2 sierpnia 1926 roku pod nazwą Ustawy zmieniającej i uzupełniającej Konstytucję Rzeczypospolitej Polskiej z dnia 17 marca 1921 roku. Nowela sierpniowa wzmacniała, osłabioną w Konstytucji Marcowej pozycję prezydenta, dając mu realny wpływ na rządy oraz pozycję Rady Ministrów kosztem uprawnień, dotychczas uprzywilejowanego Sejmu i Senatu. Art. 4 dał prezydentowi prawo rozwiązywania Sejmu i Senatu nie tylko po upływie kadencji, ale także w trakcie jej trwania. „Prezydent Rzeczpospolitej może rozwiązać Sejm i Senat przed upływem czasu, na który zostały wybrane, na wniosek Rady Ministrów umotywowane orędziem, jednakże tylko raz z tego samego powodu"18. Tym

16 Główną z nich jest przerost parlamentaryzmu. Skutkowało to niestabilnością systemu, częstymi zmianami rządów, rozdrobnieniem partyjnym, co utrudniało zbudowanie i utrzymanie stabilnej większości parlamentarnej. By wprowadzić stabilizację sytuacji politycznej często powoływano rządy pozaparlamentarne. Do problemów należało też obniżenie się poziomu debaty polityczno-publicznej, a także partyjniactwo, polegające na uznaniu interesów własnej partii ponad interes państwa. Epicentrum walki politycznej stanowiło zabójstwo Prezydenta Gabriela Narutowicza przez skrajnie prawicowego, chorego psychicznie fanatyka Eligiusza Niewiadomskiego. W wyniku tej sytuacji w kraju stała się bardzo niestabilna, funkcję prezydenta przejął dotychczasowy Marszałek Sejmu Maciej Rataj, w Warszawie wprowadzono stan wyjątkowy, a na ulicach pojawiło się wojsko. Zob.: Cz. Brzoza, L. Sowa, dz. cyt., s. 269-271.

17 Zjawisko racjonalizacji ma wiele znaczeń. Może być rozumiane jako instytucjonalizacja reguł prawnych systemu, a także wzmocnienie egzekutywy w kierunku proprezydenckim lub propremierowskim. J. Szymanek, Racjonalizacja parlamentarnego systemu rządów, „Przegląd Sejmowy" 2007, nr 1, s. 45-47.

18 T. Mołdawa, dz. cyt., s. 60 . 
samym Sejm utracił prawo rozwiązywania się mocą własnej ustawy. W czasie gdy parlament był rozwiązany prezydent miał prawo wydawać, „W razie nagłej konieczności państwowej rozporządzenia z mocą ustawy w zakresie ustawodawstwa państwowego" ${ }^{19}$. Wydawanie ich podlegało ograniczeniom temporalnym oraz merytorycznym. Do tych pierwszych zalicza się warunek nieobradowania parlamentu, a także to, iż traciły swoją moc obowiązującą jeżeli nie zostały złożone Sejmowi w ciągu $14 \mathrm{dni}$, po najbliższym jego posiedzeniu lub jeżeli po ich złożeniu Sejm ich nie uchwalił. Ograniczenia merytoryczne dotyczyły wyłączenia pewnych materii, które nie mogły być zawarte w rozporządzeniach głowy państwa. Zaliczały się do nich sprawy takie jak zmiana konstytucji, ordynacji wyborczej, finanse, ustalenie stanu liczebnego wojska, a także kwestie dotyczące spraw międzynarodowych. Rozporządzenia musiały dotyczyć spraw nagłych. Nowela przyznawała też prezydentowi uprawnienia mające zapewnić stabilizację finansową kraju. W sytuacji gdy Sejm i Senat w określonym przez nowele terminie nie uchwaliłby projektu ustawy budżetowej ani go nie odrzuciły, prezydent ogłaszał rządowy projekt jako nowa ustawę. Kosztem wzmocnienia władzy wykonawczej osłabieniu uległy uprawnienia Sejmu przy uchwalaniu rządowi wotum nieufności. Wniosek o głosowaniu wotum nieufności nie mógł być głosowany na tym samym posiedzeniu, na którym został zgłoszony. Powodowało to, że rząd zyskiwał czas na odpowiednią reakcje i mógł zapobiec uchwaleniu wotum nieufności. W praktyce konstytucyjnej pierwotny sens tego przepisu został wypaczony. Po pewnym czasie prezydent zaczął powoływać rząd według własnej opinii, nie zwracając dużej uwagi na układ sił w sejmie ${ }^{20}$. Jest to jeden z wielu przykładów, gdzie realizując postanowienia konstytucji, jednocześnie „działano sprzecznie z jej duchem”21. Wzmocniona pozycja władzy wykonawczej na bazie postanowień noweli sierpniowej w praktyce konstytucyjnej okazała się nie tylko wzmocnioną, a momentami wręcz dominującą w systemie rządów. Prezydent tak korzystał z prawa odraczania i zamykania sesji parlamentu, iż z czasem uniemożliwił parlamentowi normalną pracę. Art. 25 konstytucji wskazywał na to, że „Sejm winien być zwołany na pierwsze posiedzenie w trzeci wtorek po dniu wyborów i corocznie najpóźniej w październiku na sesję zwyczajną"22. Nie wskazywał natomiast czasu otwarcia sesji, co miało kluczowe znaczenie. Tym samym prezydent zwo-

19 Tamże.

${ }^{20}$ Sytuacja taka miała miejsce we wrześniu 1926 roku, gdy Sejm uchwalił wotum nieufności dwóm ministrom. W odpowiedzi na to posunięcie Sejmu cały rząd podał się do dymisji, a prezydent ją przyjął, po czym mianował kolejny rząd w tym samym składzie jak poprzedni; S. Krukowski, dz. cyt., s. 137.

21 Tamże.

22 Tamże, s. 32. 
ływał sesję, ale jej nie otwierał. To powodowało przedłużenie czasu w którym parlament był nieczynny. Po wyborach brzeskich w 1930 roku, zwołano sesję nadzwyczajną, po czym tego samego dnia ją odroczono i zamknięto, co doprowadziło to do tego, że formalnie odbyła się sesja, ale bez nawet jednego posiedzenia. $W$ ten sposób kontynuowano politykę interpretacji konstytucji, która zmierzała do utracenia przez parlament wpływu na skład rządu. W końcu, w sierpniu prezydent Mościcki zdecydował się rozwiązać sejm, gdy powstała skonsolidowana opozycja w postaci Centrolewu ${ }^{23}$.

Nowela sierpniowa została uchwalona po zamachu majowym, który sam $\mathrm{w}$ sobie był wymierzony przeciwko parlamentaryzmowi ustanowionemu w ustawie zasadniczej z 1921 roku. Konstytucyjne funkcje Sejmu i Senatu zostały znacząco ograniczone, a następnie praktycznie zdegradowane, co pokazała praktyka funkcjonowania systemu. Usankcjonowany prawnie w noweli sierpniowej wzrost znaczenia władzy wykonawczej zdominował cały system rządów. Główną rolę w podejmowaniu decyzji odgrywał Józef Piłsudski formalnie pozostając bez przerwy ministrem sił zbrojnych i generalnym inspektorem oraz dwukrotnie pełniąc funkcje premiera. To jego zdaniu w rzeczywistości podporządkowywali się premierzy, a także prezydent Ignacy Mościcki. Postanowienia noweli sierpniowej pchnęły Polskę na drogę autorytaryzmu. Warto zauważyć, jak wskazuje Zbigniew Czubiński, że nowela owszem spowodowała daleko idące wzmocnienie władzy wykonawczej, ale jest zapisy nadal pozostawały w ramach systemu parlamentarnego. System ten został obalony nie z dniem uchwalenia noweli, a po zamachu majowym, gdy zaczęto interpretować konstytucje marcową sprzecznie z założeniami ustawodawcy ${ }^{24}$.

\section{Konstytucja kwietniowa z 1935 roku}

Okres prac nad konstytucją kwietniową to czas szczególnie trudny dla koncepcji parlamentarno-liberalnych systemów rządów w całej Europie. Popularną alternatywą dla demokratycznego ustroju rządów stało się państwo totalne, będące zaprzeczeniem wszystkich jego dotychczasowych reguł. Odpowiedzią na światowe tendencję był polski autorytaryzm, „będący wprawdzie systemem pośrednim między państwem demokratycznym, a totalitarnym"25, który wprowadzała konstytucja kwietniowa. Po wyborach brzeskich w 1930 roku, w których Bezpartyjny Blok Współpracy

${ }^{23}$ Tamże.

${ }^{24}$ A. Czubiński, Miejsce i rola Józefa Piłsudskiego i obozu piłsudczykowskiego w odbudowie i rozwoju odrodzonego państwa polskiego, „, Kwartalnik Historyczny” 1979, nr 2, s. 491.

25 P. Sarnecki, Głowa państwa w obu polskich konstytucjach kwietniowych, „Studia Iuridica Lublinensia" 2014, nr 22, s. 299. 
z Rządem zwyciężył, lecz nie zdobył większości bezwzględnej w Sejmie, obóz sanacyjny zdawał sobie sprawę, że nowela sierpniowa nie zapewni mu całkowitej władzy w kraju. Punktem wyjścia dla powstania Konstytucji kwietniowej były tezy stworzone przez Stanisława Cara. Ich założenia całkowicie przekreślały zasady stworzone w 1921 roku przez Konstytucje marcową i od samego początku wzbudziły stanowczy sprzeciw opozycji. Konstytucja kwietniowa została uchwalona w sposób nie konstytucyjny. W 1934 roku, na posiedzeniu sejmu przedstawiono raport z prac BBWR nad projektem nowej konstytucji. Opozycja na znak protestu opuściła salę obrad, a wówczas okazało się, że tezy konstytucyjne są projektem konstytucji, którą przyjęli posłowie BBWR. Następnie Prezydent Mościcki podpisał nową ustawę zasadniczą ${ }^{26}$. W ten sposób pomajowy system rządów zmierzający w stronę autorytaryzmu został za pomocą norm konstytucyjnych formalnie utrwalony i usankcjonowany.

Nowa ustawa zasadnicza wprowadziła nadrzędność państwa nad jednostką, zlikwidowała podział władzy, za granice wolności jednostki uznawała dobro powszechne, zmarginalizowała pozycję parlamentu, a znacząco wzmocniła pozycję władzy wykonawczej, głownie prezydenta. Wysunięcie na czoło ustawy zasadniczej rozdziału poświęconego prezydentowi, a także zaznaczenie jego silnej pozycji w systemie rządów już w rozdziale pierwszym poświęconym naczelnym zasadą było konsekwencją ostatecznego zerwania z zasadą suwerenności narodu i przyjęciem zasady suwerenności państwa, którego odzwierciedleniem stała się osoba prezydenta. Art. 2 stwierdzał, że

na czele Państwa stoi Prezydent Rzeczpospolitej. Na nim spoczywa spoczywa odpowiedzialność wobec Boga i historii za losy Państwa. Jego naczelnym obowiązkiem jest troska o dobro Państwa, gotowość obronną i stanowisko wśród narodów świata.

„W jego osobie skupia się jednolita i niespodziewana władza państwowa"27. Przepis ten ukazuje jak ogromną rolę ustawodawca przypisał głowie państwa, czyniąc ją głównym organem władzy państwowej i tym samym likwidując zwierzchnictwo narodu zaakcentowane we wcześniejszej konstytucji. Mimo tak wielkiej roli i szczególnych obowiązków, prezydent nie ponosił odpowiedzialności konstytucyjnej, ani politycznej. Art. 3 wylicza organy państwowe - Rząd, Sejm, Senat, Siły Zbrojne, Kontrola Państwa pozostające pod zwierzchnictwem prezydenta, ale jednocześnie równorzędne względem siebie. Rozdział drugi, w całości poświęcony głowie państwa rozpoczyna się

\footnotetext{
${ }^{26}$ M. Pietrzak, dz. cyt., s. 500-501.

27 T. Mołdawa, dz. cyt., s. 62.
} 
artykułem 11, który kolejny raz podkreśla kluczową rolę jaką w państwie odgrywa prezydent, określając go czynnikiem nadrzędnym, harmonizującym działanie innych organów państwa. Owe harmonizowanie miało być metodą, za pomocą której prezydent miał realizować swoje zwierzchnictwo. Tryb wyboru prezydenta był tak ukształtowany, by decydująca pozycję zagwarantować ustępującemu prezydentowi. Kandydata na fotel głowy państwa wskazywało Zgromadzenie Elektorskie. Ustępujący prezydent również posiadał prawo wskazania swojego następcy. Gdyby skorzystał z tego uprawnienia, to kolejną głowę państwa wybieraliby obywatele w głosowaniu powszechnym, z pomiędzy dwóch kandydatów. Jeżeli ustępujący prezydent nie skorzystałby ze swojej możliwości wskazania kandydata w ciągu 7 dni od zrobienia tego przez Zgromadzenie Elektorskie, to automatycznie kolejnym prezydentem stawał się kandydat Zgromadzenia. Kadencja głowy państwa wynosiła 7 lat, a w przypadku wojny okres ten wydłużał się o trzy miesiące od momentu zawarcia pokoju. W razie opróżnienia urzędu prezydenta jego miejsce inaczej niż w Konstytucji marcowej zajmował Marszałek Senatu. Kompetencje, jakie przysługiwały głowie państwa na mocy Konstytucji kwietniowej można podzielić na uprawnienia z zakresu ustawodawstwa, ustrojodawstwa, władzy wykonawczej, kompetencji kontrolnych oraz prerogatyw nadzwyczajnych w okresie wojny. Do grupy tych pierwszych zalicza się wydawanie dekretów z mocą ustawy, które prezydent mógł wydawać między kadencjami Sejmu, Senatu i na podstawie upoważnienia ustawowego. Posiadał weto zawieszające, dokonywał promulgacji i publikacji ustaw. Oprócz tego zwoływał i zamykał sesje parlamentu, mianował $1 / 3$ posłów oraz posiadał prawo rozwiązania sejmu przed upływem jego kadencji. Do najważniejszych kompetencji ustrojodawczych należało prawo uprzywilejowanej inicjatywy w sprawie zmiany konstytucji oraz prawo veta $\mathrm{w}$ stosunku do poselskiego projektu zmiany konstytucji. Jeśli chodzi o uprawnienia związane z wykonywaniem władzy wykonawczej, prezydent mianował i odwoływał Prezesa Rady Ministrów, a na jego wniosek ministrów. Mianował sędziów, I Prezesa Sądu Najwyższego, sędziów Trybunału Stanu, Prezesa NIK-u oraz członków jego kolegium, Generalnego Inspektora Sił Zbrojnych. Były to prerogatywy nie wymagające kontrasygnaty ministerialnej. Wszystkie jego inne akty urzędowe wymagały podpisu premiera i właściwego ministra. Ponadto posiadał prawo łaski, reprezentował państwo na zewnątrz i posiadał zwierzchnictwo nas siłami zbrojnymi. Do kompetencji kontrolnych prezydenta należało prawo rozwiązania parlamentu, odwołania premiera, ministrów, a także prawo pociągania ich do odpowiedzialności konstytucyjnej. Mógł odwołać prezesa NIK-u i Generalnego Inspektora Sił Zbrojnych. Do nadzwyczajnych prerogatyw głowy państwa w czasie wojny 
należało zarządzanie stanu wojennego, wydawanie dekretów w materii całego ustawodawstwa, bez możliwości zmiany konstytucji, przedłużenie kadencji Parlamentu i powoływanie go w zmniejszonym stanie, mianowanie swojego następcy, naczelnego wodza. Tym samym w sytuacji wojny prezydent pełnił władzę niemalże absolutną.

Konstytucja kwietniowa byłą produktem epoki kryzysu rządów parlamentarnych, traktowanym jako lekarstwo na sytuację polityczną $\mathrm{w}$ kraju. Koncepcja silnej prezydentury wynikała z przekonania o konieczności istnienia $\mathrm{w}$ państwie czynnika nadrzędnego nad innymi organami państwowymi, który zapewniłby mu zabezpieczenie przed niebezpieczeństwami z zewnątrz, a także wyrażała w pewnym sensie nieufność do instytucji demokratycznych, które zawiodły w trakcie obowiązywania Konstytucji marcowej. Warto dodać, że konstytucja kwietniowa była tworzona na miarę cech osobowości Józefa Piłsudskiego, lecz nie dla niego samego ${ }^{28}$.

\section{Koncepcja silnej prezydentury w Republice Weimarskiej i Finlandii}

Zapoczątkowany uchwaleniem 11 sierpnia 1919 roku konstytucji, ustrój Republiki Weimarskiej uznaje się za początek systemu semiprezydenckiego. Ustawa zasadnicza została uchwalona w szczególnej sytuacji w jakiej znalazła się Rzesza Niemiecka po I wojnie światowej ${ }^{29}$. Jak wskazuje Mikołaj Labijak „konstytucja niemiecka czerpała z doświadczeń innych państw”30.

${ }^{28}$ W praktyce założenie to zawiodło, gdy zabrakło byłego Naczelnika Państwa. Prezydent Ignacy Mościcki po śmierci marszałka nie potrafił samodzielnie sprawować władzy, którą nadawała mu Konstytucja kwietniowa. Zob. szerzej: E. Gdulewicz, A. Gwiżdż, Z. Witkowski, Konstytucja Rzeczypospolitej Polskiej z 1935 r., [w:] Konstytucje Polski, red. M. Kallas, Warszawa 1990, s. 186.

${ }^{29}$ Już w ostatnich miesiącach I wojny światowej (jesień 1918) możemy mówić o rozpoczęciu historii Republiki Weimarskiej. Wśród niemieckiego społeczeństwa zaczęły wzrastać nastroje rewolucyjne domagające się obalenia monarchii, znaczenie zyskiwały radykalne, lewicowe ugrupowania. W listopadzie wybuchła rewolucja, na terenie kraju zaczęto tworzyć rady robotnicze i żołnierskie, działał Związek Spartakusa oraz Niezależna Partia Socjaldemokratyczna, których celem było powielenie scenariusza rosyjskiej rewolucji. W tej sytuacji Cesarz Wilhelm II abdykował i opuścił kraj, 9 listopada 1918 roku proklamowano republikę. 11 listopada sztab generalny podpisał zawieszenie broni. 19 stycznia 1919 w mieście Weimar odbyły się pierwsze obrady Zgromadzenia Narodowego. Miejsce to wybrano ze względu na niebezpieczną, rewolucyjną atmosferę panującą w Berlinie. Zgromadzenie Narodowe wybrało na prezydenta Friedricha Elberta i koalicyjny Tymczasowy Rząd. 5 sierpnia 1919 uchwalono nową konstytucję, która to ustanawiała zupełnie nowy ustrój w stosunku do wcześniejszej praktyki ustrojowej Niemiec. Tak szybko ustanowiona konstytucja miała przyczynić się do stabilizacji sytuacji w kraju. A. Dudek, Republika Weimarska - kryzys i stabilizacja, [w:] Historia polityczna świata XX wieku 1901-1945, red. M. Bankowicz, Kraków 2004, s. 186.

${ }^{30}$ M. Labijak, Rozwiq̨zania prawoustrojowe Republiki Weimarskiej w perspektywie historycznej i porównawczej, „Studia Iuridica Toruniensia” 2014, nr 14, s. 177. 
Szczególnie ważne w tym kontekście są doświadczenia ustrojowe III Republiki Francuskiej.

Konstytucja Republiki opierała się na zasadzie podziału władzy i suwerenności narodu. Funkcję ustawodawczą sprawował Reichstag oraz Reichsrat. Rada Państwa mająca mniejsze znaczenie, została ustanowiona w celu utrzymania federalnego charakteru Niemiec. Władzę wykonawczą wykonywał prezydent, wybierany w wyborach powszechnych, który powoływał kanclerza stojącego na czele rządów bez konieczności uzyskania zaufania w Reichstagu. Najważniejsza cechą republiki była wzmocniona pozycja prezydenta. Artykuł 41 konstytucji weimarskiej, wskazuję, iż „Prezydenta Rzeszy wybiera cały lud niemiecki"31. Wybierany w wyborach bezpośrednich miał stać się przeciwwagą dla wybieranego w wyborach bezpośrednich parlamentu. To rozwiązanie dawało mu demokratyczną legitymację do sprawowania swoich funkcji i pociągnęło za sobą nadanie kolejnych kompetencji. W świetle artykułu 43 głowa państwa sprawowała swoją kadencję przez 7 lat i mogła być wielokrotnie wybrana na tę funkcję. Kadencja prezydenta była więc prawie dwukrotnie dłuższa od wybieranego na czteroletnią kadencję parlamentu. Stwarzało to sytuację, w której zmieniony Reichstag znów stawał przed tym samym Prezydentem. Jak wskazuje Katarzyna Dunaj „nie pozostawało to bez wpływu na postrzeganie urzędu prezydenta jako gwaranta ciągłości władzy państwowej" ${ }^{32}$. Bardzo ważnym przepisem w tym kontekście jest także art. 25 dający prezydentowi prawo rozwiązania Reichstagu, ale tylko jeden raz z tego samego powodu. Prezydent, jak organ posiadający legitymację wyborczą sprawował w ten sposób kontrolę nad parlamentem, a więc organem wybranym w wyborach bezpośrednich. Głowa państwa mogła sięgnąć po to narzędzie w imię ogólnego dobra Rzeszy. W praktyce zasadę tę starano się omijać3 ${ }^{33}$. Prezydent mianował i odwoływał kanclerza Rzeszy, na którego wniosek mianował i odwoływał ministrów. Minister był powoływany przez głowę państwa aktem kontrasygnowanym przez kanclerza. Akt powołania do pełnienia funkcji kanclerza był kontrasygnowany przez niego samego. W praktyce gabinet był kreowany pod wpływem prezydenta, z uwzględnieniem zdania parlamentu, co było kwestią dorozumianą. Pozycja prezydenta była więc i w tej sferze relacji między organami władzy wyraźnie faworyzowana. Reichstag nie miał kompetencji sugerowania kandydatów do rządu, leżało to w głównie w kwestii prezydenta. Analogicznie do procesu

${ }^{31}$ M.J. Ptak, M. Kinstler, Historia państwa i prawa. Wybór tekstów źródłowych, Wrocław 1996, s. 212.

32 K. Dunaj, Weimarski model prezydentury, Warszawa 2010, s. 59.

${ }^{33}$ Powód rozwiązania parlamentu podawano w sposób bardzo lakoniczny, tak by zatrzymać możliwość zastosowania go ponownie w przyszłości. 
powoływania gabinetu, głowa państwa mogła zdymisjonować z własnej inicjatywy kanclerza, a ministrów tylko na jego wniosek. Kolejnym przykładem na to, iż przepisy konstytucji weimarskiej w wielu przypadkach na papierze ograniczały pozycję prezydenta, a w praktyce ją wzmacniały jest art. 56, według którego „Kanclerz Rzeszy ustala linie wytyczne polityki” ${ }^{34}$, za co był odpowiedzialny przed Reichstagiem. Praktyka ustrojowa republiki pokazała, że decydujący głos w tych sprawach miał jednak prezydent. Jak wspomniano już wcześniej, prezydent posiadał prawo mianowania i odwoływania kanclerza, tak więc oczywistym jest, iż tym samym zdobywał on wpływ na kształtowanie polityki państwa. Prezydent posiadał także kompetencje wydawania różnych rozporządzeń i zarządzeń, które wymagały kontrasygnaty. Taki stan rzeczy niejako uwalniał prezydenta od odpowiedzialności politycznej za akty. W klasycznym systemie parlamentarno-gabinetowym prezydent nie ponosi odpowiedzialności przed parlamentem. Odpowiedzialność ta jest przeniesiona na legislatywę przy pomocy instytucji kontrasygnaty. To rozwiązanie zostało zastosowane w konstrukcji ustrojowej Republiki, jednakże oryginalność koncepcji stanowi formuła odpowiedzialności politycznej prezydenta przed suwerenem. Idea ta była uzasadniana bezpośrednim, powszechnym wyborem prezydent przez naród. Szczególnie ważnym przepisem, podkreślającym model wzmocnionej prezydentury w konstytucji weimarskiej jest artykuł 48. Przyznawał on prezydentowi prawo wydawania zarządzeń wchodzących w materię ustaw i ją modyfikującą. W sytuacji zagrożenia bezpieczeństwa publicznego, „przewidywał ustanowienie rządów prezydenckich"35. Dawał możliwość przejściowego zawieszenia całkowicie lub tylko w części, konstytucyjnych praw i wolności, a także użycia siły w celu zmuszenia krajów związkowych do przestrzegania ustaw Rzeszy. „W razie zastosowania art. 48 konstytucyjna dyktatura prezydenta przełamywała zasadę trójpodziału władz" ${ }^{36}$. Prezydent tym samym stawał się organem nadrzędnym wobec innych. Przepis ten odegrał w praktyce ustrojowej Republiki Weimarskiej szczególną rolę. Był wykorzystywany w sytuacji zagrożenia rewolucją komunistyczną, wielkiego kryzysu gospodarczego na przełomie lat 20. i 30. Po 1925 roku artykuł ten stał się „standardowym sposobem sprawowania władzy wykonawczej”37 i służył celom politycznym, wbrew temu co pierwotnie zakładano.

Wzmocniona prezydentura występowała w tym samym okresie w Finlandii pod rządami konstytucji z 1919 roku. Obowiązujący tam od 1919 roku

\footnotetext{
${ }^{34}$ M.J. Ptak, M. Kinstler, dz. cyt., s. 214.

35 A. Dudek, dz. cyt., s. 186.

${ }^{36}$ K. Prokop, Modele stanu nadzwyczajnego, Białystok 2012, s. 225.

37 M. Labijak, dz. cyt., s. 188.
} 
Akt o formie rządu czynił finlandzki system rządów przez długi czas ${ }^{38}$ przynależnym do rodziny systemów semiprezydenckich. Konstytucja niepodległej Finlandii została uchwalona 17 lipca 1919 roku, a więc w sytuacji szczególnej dla państwa ${ }^{39}$. Podstawy ustroju Finlandii opierały się zasadzie zwierzchnictwa narodu i przedstawicielskiej formie władzy. Art. 2 wskazywał, iż „władza zwierzchnia w Finlandii należy do narodu reprezentowanego przez parlament" ${ }^{\prime 0}$. Ograniczenie władzy Eduskunty wynikało z przepisu, iż sprawuje ona władze ustawodawczą razem z prezydentem, któremu to przysługuje najwyższa władza wykonawcza. Tym samym art. 2 oprócz wyżej wymienionych zasad ustrojowych, eksponował szczególną pozycję prezydenta i dowodził zawężeniu kompetencji parlamentu tylko do władzy ustawodawczej, dzielonej z głową państwa. Do prezydenta należało prawo inicjatywy ustawodawczej, prawo stosowania weta zawieszającego, prawo do wydawania dekretów z mocą ustawy. Silną pozycję głowy państwa w systemie podkreślał sposób jej wyborów. Oprócz pierwszego prezydenta ${ }^{41}$, głowa państwa była wybierana w ogólnokrajowych wyborach dwustopniowych na sześcioletnią kadencję, a więc na okres dwukrotnie dłuższy niż parlament. Jak wskazuje Dawid Michalski „Akt o formie rządów z 1919 r. był na ówczesnym etapie rozwoju fińskiej państwowości dokumentem niezbędnym"42. Po odzyskaniu niepodległości w 1918 roku, Finlandia by zapewnić stabilne przywództwo $w$ sytuacji kryzysów wewnętrznych potrzebowała silnej głowy państwa.

38 Powstała na bazie reform z lat 90. Konstytucja Finlandii z 11 czerwca 1999 roku przekształciła dotychczasową postać systemu państwa, zmieniając akcenty ważności w trójkącie relacji - prezydent, rząd, parlament.

39 Do 1917 Finlandia funkcjonowała jako autonomiczne terytorium Imperium Rosyjskiego połączone z nim unią personalną. Uzyskując niepodległość 6 grudnia 1917 roku, po raz pierwszy pojawiła się na mapie jako państwo niezależne. W 1918 w kraju wybuchła wojna domowa pomiędzy zwolennikami uniezależnienia się od wpływów radzieckich i rewolucjonistami, którzy byli wspierani przez bolszewików o formę rządów państwa. Po jej zakończeniu, na fińskiej scenie politycznej rozpoczęła się rywalizacja pomiędzy zwolennikami republiki, a monarchistami. W 1919 roku odbyły się wybory w których zwyciężyły ugrupowania tych pierwszych; D. Michalski, Akt o Formie rzq̨dów z 1919 roku - pierwsza konstytucja niepodległej Finlandii, „Studia z Dziejów Państwa i Prawa Polskiego” 2016, nr 19, s. 245.

${ }^{40}$ Konstytucja Republiki Finlandii z dnia 11 czerwca 1999 r., J. Osiński (tłum.), Warszawa 2003, http://libr.sejm.gov.pl/tek01/txt/konst/finlandia.html (dostęp: 12.05.2019).

${ }^{41}$ Pierwszy prezydent miał być wybrany przez parlament. Było to spowodowane sytuacją wewnątrz państwa. Brakiem określonego trybu wyboru elektorów do głosowania powszechnego oraz procedury wyboru przez ich kolegium. M. Grzybowski, Semiprezydencjalizm złagodzony: pozycja ustrojowa Prezydenta Finlandii na tle doświadczeń V Republiki Francuskiej, „Studia Iuridica Leblinensia” 2014, nr 22, s. 68.

${ }^{42}$ D. Michalski, dz. cyt., s. 254. 


\section{Wnioski}

Omawiana tematyka rozwiązań konstytucyjnych przyjętych w czasie dwudziestolecia międzywojennego przez Rzeczpospolitą Polskę jest kluczowa w rozumieniu kształtowania się i ewolucji roli prezydenta jako organu władzy wykonawczej. Okres ten można uznać za czas różnego rodzaju testów rozwiązań konstytucyjnych, które w mniejszym lub większym stopniu sprawdziły się w praktyce. Dekret z 1919 roku o najwyższej władzy reprezentacyjnej Republiki Polskiej co prawda nie wprowadzał urzędu Prezydenta, ale typowe dla silnej prezydentury funkcje powierzał Tymczasowemu Naczelnikowi Państwa. Mała Konstytucja z 1919 roku ustanawiała rządy parlamentarne w zaostrzonej postaci. Konstytucja marcowa podtrzymała tę tendencję, jednakże w złagodzonej formie wprowadzając słaby urząd prezydenta. Regulacje zawarte $\mathrm{w}$ tej ustawie zasadniczej nie doprowadziły do stabilności systemu, a długotrwały konflikt pomiędzy ugrupowaniami parlamentarnymi doprowadził do permanentnego konfliktu, który zakończył autorytarny akt jakim był zamach stanu przeprowadzony w maju 1926 roku. Zabiegi racjonalizacyjne podjęte w noweli sierpniowej, a następnie w Konstytucji Kwietniowej z 1935 roku w kierunku wzmocnionej władzy prezydenta, służyły usprawnieniu działania systemu, lecz trudno ukryć fakt, że sankcjonowały one władzę obozu piłsudczykowskiego, który objął rządy w niedemokratyczny sposób i pchnął Polskę na drogę autorytaryzmu. Warto mieć na uwadze, iż polskie rozwiązania dotyczące pozycji głowy państwa w systemie wpisują się nurt wzmocnionej władzy wykonawczej w latach 20 ., 30. XX wieku, czemu dowodzi przykład Republiki Weimarskiej czy też Finlandii. System rządów Republiki Weimarskiej uznawany jest za model, który dał początek systemowi semiprezydenckiemu, gdzie prezydent posiada silną pozycję. Kwestią sporną pozostaje czy jest on nowym, samodzielnym rodzajem systemu, czy też jeszcze odmianą zracjonalizowanego parlamentaryzmu, niemniej jednak jest to ustrój rządów z wyraźnie zaznaczająca się wzmocnioną pozycją głowy państwa. Podobne rozwiązania ustrojowe obserwujemy w Finlandii pod rządami konstytucji z 1919 roku. Akt o formie rządów niewątpliwie wprowadzał silną koncepcje prezydentury w tym systemie.

Powyższa przekrojowa analiza rozwiązań konstytucyjnych w kontekście wzmocnionej prezydentury ukazuje różnorodność przyjmowanych rozwiązań w niemieckim, finlandzkim i polskim ustawodawstwie konstytucyjnym. Model silnej prezydentury wprowadzony w Polsce, Republice Weimarskiej, a także Finlandii pod rządami konstytucji z 1919 roku łączy szczególna sytuacja tych państw. W Polsce była ona odpowiedzią na powtarzające się 
kryzysy parlamentarne i stanowiła wyraz autorytarnych tendencji obozu piłsudczyków. Niemcy osłabione po I wojnie światowej były narażone na wybuch rewolucji komunistycznej, natomiast Finlandia w 1917 roku pojawiła się po raz pierwszy na mapie świata jako autonomiczne terytorium, którego egzystencja była zagrożona z zewnątrz i z wewnątrz. Widzimy więc, że wprowadzenie modelu wzmocnionej prezydentury w tych przypadkach było spowodowane trudną sytuacją wewnętrzną i zewnętrzną państwa. Dyskusyjną pozostaje kwestia, czy w tych przypadkach racjonalizacja w kierunku wzmocnionej pozycji prezydenta w systemie rządów doprowadziła do stabilizacji systemu. Republika Weimarka, mimo wielu dokonaniom, stanowiła formę przejściową do totalitaryzmu III Rzeszy. Demokratyczne założenia konstytucji nie uchroniły w latach 30 . Niemców od rosnącej w siłę ideologii totalitarnej. Zupełnie inaczej sprawy potoczyły się w Finlandii. To właśnie nadanie silnych prerogatyw prezydentowi usprawniło działanie i utrwaliło niepodległość państwa w okresie II wojny światowej i stanowiło fundament pod przyszły zreformowany w 1991 roku ustrój.

\section{BIBLIOGRAFIA}

\section{Źródła drukowane}

Gdulewicz E., Gwiżdż A., Witkowski Z., Konstytucja Rzeczypospolitej Polskiej z 1935 roku, [w:] Konstytucje Polski, red. M. Kallas, Państwowe Wydawnictwo Naukowe, Warszawa 1990.

Konstytucja Finlandii, J. Osiński (tłum.), Wydawnictwo Sejmowe, Warszawa 1997, http://libr. sejm.gov.pl/tek01/txt/konst/finlandia97-a.html (dostęp: 12.05.2019).

\section{Opracowania}

Ajnenkiel A., Konstytucje Polski w rozwoju dziejowym 1791-1997, Oficyna Wydawnicza RYTM, Warszawa 2001.

Balicki R., Małe konstytucje w polskim prawie konstytucyjnym, [w:] Studia nad prawem konstytucyjnym, red. J. Trzciński, B. Banaszak, Wydawnictwo Uniwersytetu Wrocławskiego, Wrocław 2005.

Brzoza Cz., Sowa L., Historia Polski 1918-1945, Wydawnictwo Literackie, Kraków 2006.

Czubiński A., Miejsce i rola Józefa Piłsudskiego i obozu piłsudczykowskiego w odbudowie i rozwoju odrodzonego państwa polskiego, „Kwartalnik Historyczny” 1979, nr 2.

Dudek A., Historia polityczna Polski 1989-2012, Wydawnictwo Znak, Kraków 2013.

Dudek A., Republika Weimarska - kryzys i stabilizacja, [w:] Historia polityczna świata XX wieku 1901-1945, red. M. Bankowicz, Wydawnictwo Uniwersytetu Jagiellońskiego, Kraków 2004. 
Dunaj K., Weimarski model prezydentury, Dom Wydawniczy Elipsa, Warszawa 2010.

Garlicki L., Polskie prawo konstytucyjne zarys wykładu część 2, Liber, Warszawa 1998.

Gdulewicz E., Gwiżdż A., Witkowski Z., Konstytucja Rzeczypospolitej Polskiej z 1935 r., [w:] Konstytucje Polski, red. M. Kallas, Państwowe Wydawnictwo Naukowe, Warszawa 1990.

Grzybowski M., Finlandia zarys systemu ustrojowego, Wydawnictwo Uniwersytetu Jagiellońskiego, Kraków 2007.

Kallas M., Konstytucja Rzeczpospolitej Polskiej, Wydawnictwo Prawnicze PWN, Warszawa 2001.

Kraczkowski R., Mała konstytucja z dnia 20 lutego 1919 r., [w:] Małe konstytucje. Ustawy zasadnicze okresów przejściowych 1919-1947-1992, red. R. Jastrzębski, M. Zubik, Wydawnictwo Sejmowe, Warszawa 2014.

Krukowski S., Nowela sierpniowa z 1926 r., [w:] Konstytucje Polski, red. M. Kallas, Państwowe Wydawnictwo Naukowe, Warszawa 1990.

Labijak M., Rozwiqzzania prawoustrojowe Republiki Weimarskiej w perspektywie historycznej i porównawczej, „Studia Iuridica Toruniensia” 2014, nr 14.

Michalski D., Akt o Formie rządów z 1919 roku - pierwsza konstytucja niepodległej Finlandii, „Studia z Dziejów Państwa i Prawa Polskiego” 2016, nr 19.

Mołdawa T., Konstytucje Polskie 1918-1998, Dom Wydawniczy Elipsa, Warszawa 1999.

Muszyński J., Prezydentura w Polsce, Wydawnictwo ATLA 2, Wrocław 2002.

Pietrzak M., Druga Rzeczpospolita, [w:] Historia ustroju i prawa polskiego, red. J. Bardach, B. Leśnodorski, M. Pietrzak, Wydawnictwo Prawnicze PWN, Warszawa 1999.

Prokop K., Modele stanu nadzwyczajnego, Wydawnictwo Temida 2, Białystok 2012.

Ptak M.J., Kinstler M., Historia państwa i prawa. Wybór tekstów źródłowych, Wydawnictwo Uniwersytetu Wrocławskiego, Wrocław 1996.

Sarnecki P., Głowa państwa w obu polskich konstytucjach kwietniowych , „Studia Iuridica Lublinensia" 2014, nr 22.

Serzhanova V., Konstytucje finlandzkie, „Zeszyty Naukowe Instytutu Administracji Akademii im. Jana Długosza w Częstochowie" 2006, nr 4.

Serzhanova V., Zmiana formy rządu w najnowszej konstytucji Finlandii, „Zeszyty naukowe Uniwersytetu Rzeszowskiego" 2011, nr 71.

Szymanek J., Racjonalizacja parlamentarnego systemu rządów, „Przegląd Sejmowy” 2007, nr 1. 
Weronika Nawracaj

\title{
FORMATION OF PRESIDENCY IN THE SECOND POLISH REPUBLIC IN COMPARISON TO A CONCEPT OF STRENGHTENED PRESIDENCY IN THE WEIMAR REPUBLIC AND FINLAND UNDER THE CONSTITUTION OF 1919
}

\begin{abstract}
A fter gaining independence on November 11,1918 , Poland faced many challenges. The state was a creation formed of the combined territories of the Prussian, Austrian and Russian partitions, which for 123 years were subordinated to different legal systems of the partitioning states. Independent Poland quickly had to work out the foundations for its own new system. This was not facilitated by the struggle for the borders of the Polish state, economic problems, the lack of a coherent centre of power and many other factors destabilizing the situation in the state. Józef Piłsudski had a great influence on the relationship between the main organs of government on the basis of constitutional law and he also managed to combine local governments into a single authority, and thus created the germ of the Second Polish Republic. The analysis of the Polish constitutional solutions shaping the presidency at that time will be enriched with considerations on the introduction of the concept of a strong presidency in the Weimar Republic, and also in Finland under the constitution of 1919. The introduced solutions shaping the presidency against the background of Polish constitutionalism, as well as German and Finnish constitutionalism, will be analysed in terms of rationalizing the system towards a strengthened head of state. The analysis of these solutions will allow to state that the Polish legislator introduced solutions typical of the concept of a strong presidency on the basis of the August Novelisation of 1926 and the April Constitution of 1935.
\end{abstract}

Keywords: strengthened executive power, presidency, Second Polish Republic, Weimar Republic, Finland. 